\title{
Effect of different periods of hyperbaric oxygen on ischemia-reperfusion injury of rat small bowel ${ }^{1}$
}

\author{
Efeitos de diferentes períodos de oxigenação hiperbárica na lesão de isquemia e \\ reperfusão de intestino delgado de ratos
}

\author{
Paulo Roberto BertolettoI, José Carlos Chaves", Anna Tereza Negrini Fagundes ${ }^{\mathrm{III}}$, Ricardo Santos Simões ${ }^{\mathrm{IV}}$, Celina

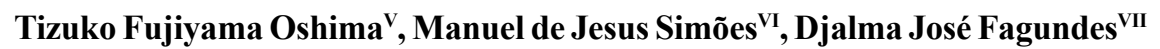 \\ ${ }^{\text {I }}$ Master, Assistant Professor, Surgical Gastroenterology, University of Grande Dourados (UFGD), Mato Grosso do Sul, Brazil. \\ II Master, Assistant Professor, Surgical Anatomy, UFGD, Mato Grosso do Sul, Brazil. \\ III Graduate Student, Medical School, Santo Amaro University (UNISA), São Paulo, Brazil. \\ IV Graduate Student, Medical School, Federal University of São Paulo (UNIFESP), Brazil. \\ V PhD, Affiliate Professor, Molecular Pathology Division, Department of Pathology, UNIFESP, São Paulo, Brazil. \\ ${ }^{V I}$ Full Professor, Head of Histology and Structural Biology Division, Department of Morphology, UNIFESP, São Paulo, Brazil. \\ ${ }^{V I I}$ PhD, Associate Professor, Surgery Division of Operative Technique and Experimental Surgery, Department of Surgery, UNIFESP, \\ São Paulo, Brazil.
}

\begin{abstract}
Purpose: To determine whether hyperbaric oxygen (HBO) could effectively protect the small intestine mucosa against an ischemic insult, according to different periods of application. Methods: The gut of 32 male rats was subjected to 60-min ischemia (clamping the mesenteric artery and vein); After they were further reperfused upon clamp opening during $60 \mathrm{~min}$. Animal groups were as follows. GII = placed on $\mathrm{HBO}$ during the ischemia period; GIII = placed on HBO during reperfusion; $\mathrm{GIV}=$ treated with HBO throughout the ischemia-reperfusion period. Some animals (GI) did not receive HBO treatment at all and served as reference of ischemia-reperfusion injury (IR). HBO was carried out in a cylindrical acrylic chamber (2.0 ATA). Samples of small bowel were prepared for H.E staining for histological evaluations. Results: The histological injury of mucosa was significantly less when HBO was administered during the ischemia period (17.6 \pm 0.6$)$ as compared with the $\operatorname{IR}(21.3 \pm 1.8)$. HBO was not effective when applied during reperfusion $(23.1 \pm 2.1)$ or during the ischemia plus reperfusion period $(18.7 \pm 1.9)$. The thickness of the mucosa was preserved by HBO in ischemia $(327.50 \pm 30.23 \mu \mathrm{m})$ in comparison with the IR $(172.79 \pm 5.95 \mu \mathrm{m})$. In the periods of reperfusion $(162.50 \pm 6.05 \mu \mathrm{m})$ and ischemia plus reperfusion $(296.49 \pm 20.01 \mu \mathrm{m})$ the mucosa revealed a structural injury. Conclusion: Hyperbaric oxygen affects the ischemic insult of small bowel, being the favorable effect obtained when hyperbaric oxygen was administered early in the ischemic period.
\end{abstract}

Key words: Hyperbaric Oxygenation. Ischemia. Intestine, Small, Rats.

\section{RESUMO}

Objetivo: Determinar se a oxigenação hiperbárica (OHB) protege a mucosa do intestino delgado de ratos após isquemia e reperfusão. Métodos: 32 ratos machos foram submetidos a clampeamento da artéria e da veia mesentéricas superiores durante 60 minutos (isquemia) seguido de 60 minutos de reperfusão. Após estes procedimentos os animais fora separados em quatro grupos, a saber: grupo I (GI) isquemia e reperfusão (IR); grupo II (GII) submetido a OHB concomitante a isquemia, Grupo III (GIII) submetido a OHB durante a reperfusão e, grupo IV (GIV) submetido a OHB durante o período de isquemia e de reperfusão. A OHB foi realizada em câmara acrílica (2.0 ATA). Após anestesia, fragmentos do intestino delgado (íleo) foram fixados e processados para inclusão em parafina sendo os cortes corados pelo HE. As lâminas foram avaliadas quanto a presença de lesões histopatológicas da mucosa e avaliado a espessura da mucosa. Resultados: A lesão histopatológica da mucosa foi significativamente inferior quando a OHB foi administrada na isquemia (12.6 \pm 0.6$)$ em comparação com o IR (21.3 \pm 1.8$)$. A OHB não foi efetiva quando aplicada durante a reperfusão (23.1 \pm 2.1$)$, ou durante a isquemia e reperfusão (18.7 \pm 1.9$)$. A espessura da mucosa foi preservada pela OHB na isquemia $(327,50 \pm 30.23 \mu \mathrm{m}) \mathrm{em}$ comparação com o IR $(172.79 \pm 5.95 \mu \mathrm{m})$. Nos períodos de reperfusão $(162.50 \pm 6.05 \mu \mathrm{m})$ e a isquemia $(296.49 \pm 20.01 \mu \mathrm{m}) \mathrm{a}$ mucosa apresentou lesão estrutural. Conclusão: A oxigenação hiperbárica protege a mucosa intestinal quando realizada durante o período de isquemia.

Descritores: Oxigenação Hiperbárica. Isquemia. Intestino Delgado. Ratos.

1. Research performed at Surgery and Experimentation Post-Graduate Program, Federal University of São Paulo (UNIFESP), Brazil. 


\section{Introduction}

Postoperative complications after intestinal transplantation can be ascribed to hypothermic storage and reperfusion injury ${ }^{1,2}$. The small bowel villi are extremely sensitive to ischemia-reperfusion (IR) injury and a number of microcirculatory disturbances contribute to structural and functional changes ${ }^{1,3}$.

Treatment with hyperbaric oxygen (HBO) has shown promising results in some models of ischemia, the major effect being a reduction in the local ischemic damage 4-6.

A current experimental model induced a controlled intestinal I/R injury in rats by occlusion of a first-order branch of the superior mesenteric artery. The elapsed time of ischemia (minutes to hours), as the ensuing reperfusion time (minutes to hours), are factors handled in different manners ${ }^{7}$. In a model with rats subjected to 30 minutes of ischemia followed by 30 minutes of reperfusion it was reported a histologically-evidenced protective effect on the small bowel villi when $\mathrm{HBO}$ was applied during the ischemia period $^{8,9}$.

Our aim was to determine whether HBO could offer a distinct protection to the small intestine mucosa depending on the period of appliance: only during the ischemia, only during the reperfusion or during both ischemia and reperfusion periods.

\section{Methods}

The experimental protocol was approved by the Ethics Committee of the Federal University of São Paulo Escola Paulista de Medicina (UNIFESP - EPM). All the procedures followed strictly the existing regulations about animal experimentation

Thirty-two male Wistar rats weighing 250-300 g were fed standard rat chow and water ad libitum. All the surgical procedures and $\mathrm{HBO}$ were performed under general anesthesia, using ketamine (60mg. $\left.\mathrm{Kg}^{-1}\right)$ and xylazine (5mg. $\left.\mathrm{Kg}^{-1}\right)$.

All the animals were subjected to laparotomy and the principal branches of the superior mesenteric artery and vein were interrupted with a bulldog clamp and a temporary suture was performed. After 60 minutes the bulldog clamp was removed. Upon 60 minutes of reperfusion the entire small bowel was removed. Three specimens from the distal intestine (about $5 \mathrm{~cm}$ from the ileo-colon transition) $\mathrm{HBO}$ was carried out in a cylindrical acrylic chamber ${ }^{10}$. Before pressurization, $100 \%$ medical oxygen was flushed through the chamber for $5 \mathrm{~min}$ to displace the room air. Oxygen pressure was then increased at a constant rate to reach a pressure of 2.0 ATA. The oxygen concentration was monitored with a calibrated oxymeter. The animals were placed in the hyperbaric chamber in accordance to their randomly assigned groups. The animals of Group I $(n=8)$ did not receive the HBO treatment, the Group II $(\mathrm{n}=8)$ received the $\mathrm{HBO}$ only during the 60 minutes of ischemia, the Group III $(n=8)$ received HBO only during the 60 minutes of reperfusion, and the Group IV $(\mathrm{n}=8)$ received the HBO both during the 60 minutes of ischemia and the ensuing 60 minutes of reperfusion.

Samples of the small bowel tissue were fixed in $10 \%$ formalin solution, embedded in paraffin wax and $5 \mu \mathrm{m}$ sections were cut and stained with hematoxilin and eosin. Histological evaluation was undertaken by an independent pathologist who had no knowledge of the experimental groups from which the specimens were derived. The macroscopic assessment was performed using the follow grading scoring: 0 (no changes), 1 (mild), 2 (moderate) and 3 (severe). The abnormalities detected in 20 random sites in every animal plate were subjectively scored and compared with the controls. The evaluated parameters were mucosal ulceration, mucosal necrosis, edema, inflammatory cell infiltration, crypt abscess, mucosal atrophy, and erosion. The tissue injury was evaluated by the sum of parameters (minimum $=0$ to maximum $=24$ ). The sections were carefully examined microscopically and the best observed areas were selected for morphometric studies. The images were captured in 20 selected areas per histological section of the small bowel mucosa with a high-resolution AxioCam ${ }^{\circledR}$ camera coupled to a Carl Zeiss Axilab ${ }^{\circledR}$ light microscope, by the AxioVision-Rel ${ }^{\circledR}$ software (Zeiss). The thickness was calculated from the muscularis mucosa up to the most prominent villous in the intestinal crypt or lumen using the AxioVisionRel ${ }^{\circledR}$ software.

The significance of the differences in histological scores and in thickness measurements were made by ANOVA test and the post-hoc Tukey-Kramer test. A $P$ value $<0.05$ was considered to be statistically significant.

\section{Results}

\section{Morphological}

The results showed complete destruction of intestinal villi and hemorrhagic areas in the submucosa in the small bowel of the animals in group I (IR) and group III (HBO during reperfusion). The histological sections of the small bowel from the animals of group II (HBO during the ischemia period) and those of group IV showed a preserved, normal mucosa structure, with mild hemorrhagic areas at the submucosal level and a mild necrosis of enterocytes at the apex of the villi, with some preservation of the normal mucosal structure (Figure 1).

\section{Morphometric}

The measured thickness of mucosa and the histological scores of small bowel injury are shown in Table 1. 
TABLE 1 - Mucosal thickness and histological scores of the ischemic injury imposed to the small bowel mucosa. Values are given as mean $\pm \mathrm{SD}$

\begin{tabular}{lll} 
Group & Mucosa thickness $(\boldsymbol{\mu m})$ & Mucosal injury scores \\
\hline GI (Ischemia-reperfusion) & $172.79 \pm 5.95^{\mathrm{a}}$ & $21.3 \pm 1.8^{\mathrm{a}}$ \\
GII (HBO during ischemia) & $327.50 \pm 30.23^{\mathrm{b}}$ & $17.6 \pm 1.6^{\mathrm{b}}$ \\
GIII (HBO during reperfusion) & $162.50 \pm 6.05^{\mathrm{a}}$ & $23.1 \pm 2.1^{\mathrm{a}}$ \\
GIV (HBO during ischemia-reperfusion) & $296.49 \pm 20.01^{\mathrm{b}}$ & $18.7 \pm 1.9^{\mathrm{b}}$ \\
\hline
\end{tabular}

All animals were subjected to 60-min intestinal ischemia and some of them were reperfused upon clamp opening during 60 min (see Mat \& Meth). GII animals were treated with hyperbaric oxygen (HBO) during the ischemia period; those of GIII were treated with HBO during reperfusion; those of GIV were treated with HBO throughout the ischemia-reperfusion period. Some animals (GI) did not receive HBO treatment at all and served as "controls". Different superscript letters indicate statistically significant differences with regard to the corresponding control (GI) value (ANOVA, $P<0.001$ ).

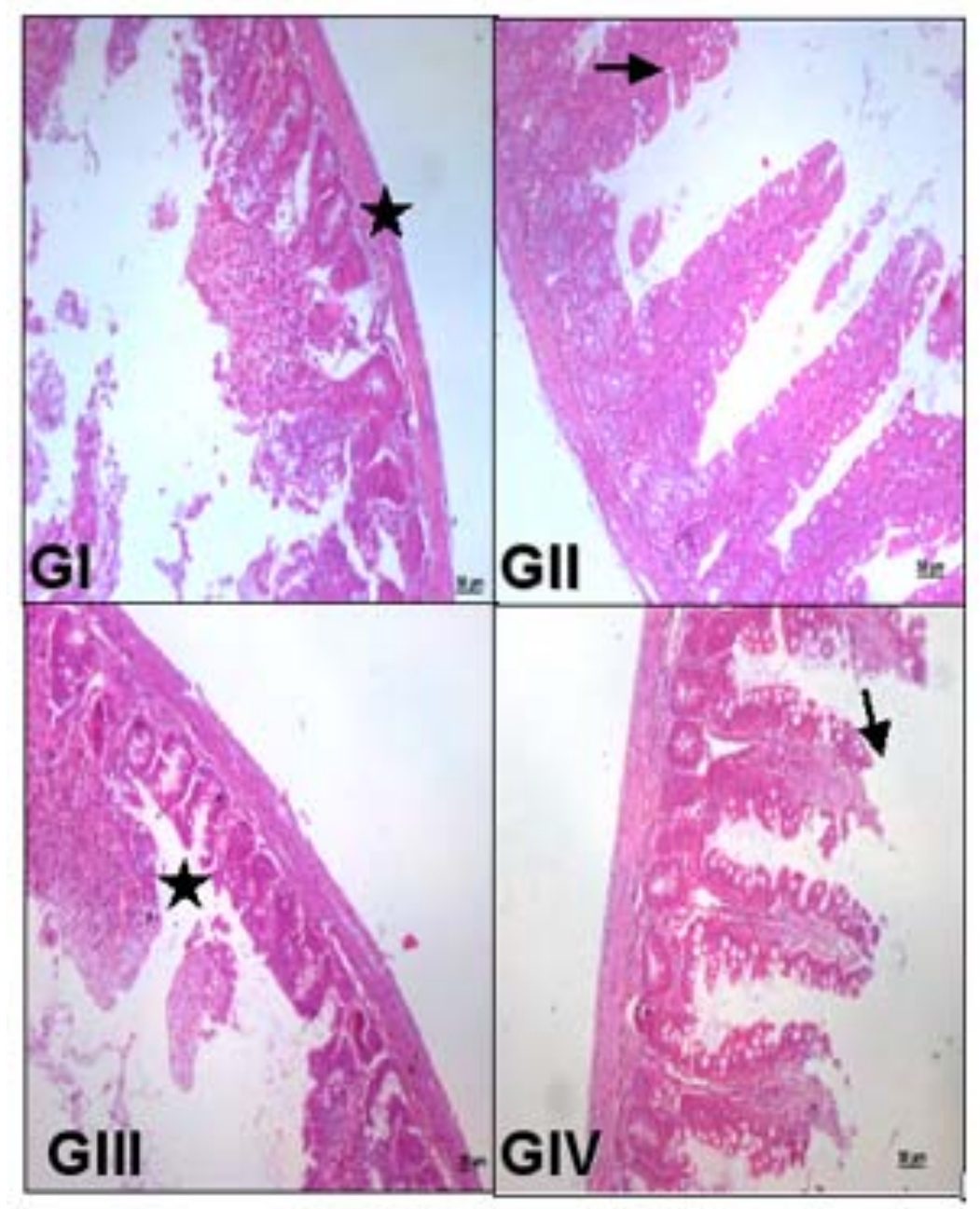

FIGURE 1 - Typical cross sections of the small bowel of animals subjected to intestinal ischemia by 60 -min occlusion of the superior mesenteric artery. Hyperbaric oxygen (HBO) was applied during the ischemia and/or reperfusion periods. In the groups I (ischemia-reperfusion) and III (HBO during reperfusion) it can be observed complete destruction of the intestinal villi $(*)$. The groups II (HBO during ischemia) and IV (HBO during ischemia-reperfusion) showed preservation of normal structure of the mucosa with areas of necrosis of enterocytes at the apex of the villi (arrows). (H.E. 100X) 


\section{Discussion}

In this paper we found different responses of the small bowel subjected to ischemia reperfusion (IR) injury to HBO treatment. Our results demonstrated an effective protection of the mucosa when HBO supplied during the ischemia time. The scores of histological injury as the thickness mucosa were significantly improved in comparison with the controls. On the other hand, when HBO occurred during the reperfusion time or during the entire procedure (ischemia plus reperfusion) the results were not different or even worse than those of the controls. These data demonstrated a connection between HBO treatment and alleviated intestine injury, although this depended upon the period when the HBO treatment was supplied.

Despite numerous reports about the positive effects of HBO in several clinical and experimental situations, their exact mechanism of action are not well known ${ }^{11,12}$, although part of them are currently being attributed to a reduction of the oxidative stress and inhibition of cytokine release ${ }^{13}$. HBO stimulates aerobic metabolism to preserve energy-rich compounds ${ }^{11,13}$ and thus can reduce nitric oxide synthase (NOS) activity, increase the superoxide dismutase (SOD) activity, and decrease the levels of malondialdehyde ${ }^{14}$. These activities were related to the pathological cascade of free radical reactions and further yields more reactive oxidative specimens (ROS) that were responsible to impair the cellular structure and function. The fact that restoration of blood flow can save the intestine, but results in cellular dysfunction and death has led to extensive clinical and experimental studies.

Our results suggest that the clear reduction in the severity of histological injuries was probably due to the large amount of oxygen offered to the tissue in the ischemia time and consequent reduction of ROS in the further period of reperfusion. We hypothesize that HBO may achieve its beneficial effects by preserving high-energy compounds ${ }^{1}$ limiting hypoxic/ischemic-induced lipid peroxidation ${ }^{15}$ and modifying the inflammatory process.

When HBO was applied during the reperfusion period, the excessive oxygen rates promote an increase of ROS production and severe structural impairment of the small bowel mucosa. These data support the view that an intestinal injury is sustained during the periods of ischemia and the HBO treatment in the ensuing period of reperfusion does not reduce the injury thereby produced. The results suggest that HBO should be administered early as the ischemia is installed, in order to avoid the IR injury and to obtain a favorable effect.

\section{Conclusions}

There was a connection between the HBO and small bowel IR injury. The favorable effect was obtained when $\mathrm{HBO}$ was administered early during the ischemia time. The HBO in further periods of reperfusion was associated to more severe mucosa injury.

\section{References}

1. Offner FA, Königsrainer A, Klaus A, Margreiter R. Pathology of small intestine transplantation. Verh Dtsch Ges Pathol. 2004;88:106-12.

2. Cruz RJ, Correia CJ, Ribeiro CM, Poli de Figueiredo LF, Rocha e Silva M. Oxygen consumption, pCO2 gradients and regional blood flow distribution in an alternative model of intestinal autotransplantation. J Surg Res. 2006;130(1):13-9.

3. Tjärnström J, Wikström T, Bagge U, Risberg B, Braide M. Effects of hyperbaric oxygen treatment on neutrophil activation and pulmonary sequestration in intestinal ischemia-reperfusion in rats. Eur Surg Res.1999;31(2):147-54.

4. Yu SY, Chiu JH, Yang SD, Yu HY, Hsieh CC, Chen PJ, Lui WY, Wu CW. Preconditioned hyperbaric oxygenation protects the liver against ischemia-reperfusion injury in rats. J Surg Res. 2005;128(1):28-36.

5. Martin AE, Luquette MH, Besner GE. Timing, route, and dose of administration of heparin-binding epidermal growth factor-like growth factor in protection against intestinal ischemia-reperfusion injury. J Pediatr Surg. 2005;40(11):1741-7.

6. Guimarães FA, Taha MO, Simões MJ, Fagundes DJ. Ischemia-reperfusion of the small intestine and hyperbaric oxygen treatment: a morphologic study in rats. Transplant Proc. 2002;34(3):977-9.

7. Stallion A, Kou TD, Latifi SQ, Miller KA, Dahms BB, Dudgeon DL, Levine AD. Ischemia/reperfusion: a clinically relevant model of intestinal injury yielding systemic inflammation. J Pediatr Surg. 2005;40(3):4707.

8. Pascher A, Klupp J. Biologics in the treatment of transplant rejection and ischemia/reperfusion injury: new applications for TNFalpha inhibitors? BioDrugs. 2005;19(4):211-31.

9. Guimarães FA, Taha MO, Simões MJ, Moino CA, Santos IV, Amador JC, Santos RA, Queiroz RB, Amaro RR, Jesus MA, Caricati-Neto A. Use of hyperbaric oxygenation in small bowel preservation for transplant. Transplant Proc. 2006;38(6):1796-9.

10. Pereira, MLL, Teles, AP, Pereira Neto J. Câmara hiperbárica de acrílico para animais de pequeno porte. Acta Cir Bras. 2001;6(4):267-70.

11 -Yamada T, Taguchi T, Hirata Y, Toyohara T, Hirose R, Suita S, Yagi H. The effect of hyperbaric oxygenation on ischemia-reperfusion injury of the small intestine. Transplant Proc. 1994;26:1506-7. 
12. Rachmilewitz D, Karmeli F, Okon, Rubenstein I, Better OS. Hyperbaric oxygen: a novel modality to ameliorate experimental colitis. Gut. 1998;43(4):512-8.

13. Nylander G, Nordstrom H, Lewis D, Larsson J. Metabolic effects of hyperbaric oxygen in postischemic muscle. Plast Reconstr Surg. 1987;79:91-7.

14. Gulec B, Yasar M, Yildiz S, Oter S, Akay C, Deveci S, Sen D. Effect of hyperbaric oxygen on experimental acute distal colitis. Physiol Res.2004;53(5):493-9.

15. Thom SR. Antagonism of carbon monoxide-mediated brain lipid peroxidation by hyperbaric oxygen. Toxicol Appl Pharmacol. 1990;105:340-44

\section{Correspondence:}

Paulo Roberto Bertoletto

Rua João Rosa Góes, 1290

79805-010 Dourados - MS Brazil

Phone: (55 67)421-5960

bertoletto@terra.com.br
Conflict of interest: none Financial source: none

Received: August 14, 2007

Review: October 15, 2007

Accepted: November 12, 2007

\section{How to cite this article}

Bertoletto PR, Chaves JC, Fagundes ATN, Simões RS, Oshima CTF, Simões MJ, Fagundes DJ. Effect of different periods of hyperbaric oxygen on ischemia-reperfusion injury of rat small bowel. Acta Cir Bras. [serial on the Internet] 2008 JanFeb;23(1). Available from URL: http://www.scielo.br/acb

\footnotetext{
* Color figure available from www.scielo.br/acb
} 